\title{
Biomarkers and genetic factors for early prediction of pre-eclampsia
}

\author{
Hannah Kim and Sung Shin Shim* \\ Department of Obstetrics and Gynecology, CHA Gangnam Medical Center, CHA University, Seoul, Korea
}

\begin{abstract}
Pre-eclampsia is known to cause considerable maternal morbidity and mortality. Thus, many studies have examined the etiopathogenesis of pre-eclampsia. While many pathophysiological factors related to pre-eclampsia have been identified, the precise etiopathogenesis of pre-eclampsia remains unclear. Numerous studies have identified factors for the early prediction for pre-eclampsia to lead to preparation and closer observation on pre-eclampsia when it occurs. This article reviews on current studies of biomarkers and genetic factors related to pre-eclampsia, which may be important for developing strategies for early prediction of pre-eclampsia.
\end{abstract}

Key words: Pre-eclampsia, Biomarkers, Genes, Cell-free nucleic acids, Early detection of disease.

\section{Introduction}

Pre-eclampsia (PE) is a disorder that occurs in multiple systems during pregnancy and it causes considerable maternal morbidity and mortality. PE is a serious complication characterized by high blood pressure and proteinuria, and it can lead to multiple organ damages. It typically develops after 20 weeks of pregnancy, but it can occur at any time during labor, or even up to 6 weeks after delivery. PE can become severe very quickly or progress slowly. Left untreated, PE can lead to dangerous-or even fatal-complications for both the mother and fetus, such as HELLP (hemolysis, elevated liver enzymes, and low platelets) syndrome and eclampsia [1-3].

The pathogenesis of PE remains unclear despite extensive research over the past few decades. However, multiple factors related to $P E$ including maternal and fetal/placental factors have been identified. In PE, invasion of the maternal uterine spiral arteries into the placental trophoblast is inadequate. This is one of the main causes of poor placental perfusion and leads to placental and fetal hypoxia. Hypoxia is a potent stimulus for release of the numerous factors into the maternal circulation that may affect endothelial function of maternal system, and this can be reason of hypertension and other signs of the disease.

Currently, PE is thought to result from defective spiral artery remodeling, leading to cellular ischemia in the placenta and resulting widespread endothelial dysfunction of maternal multiorgan systems. Exact etiology underlying the cellular and molecular mechanisms of PE is still elusive. But recent observations support that altered expression of multiple factors is responsible for the clinical manifestation of the disease [4].

PE is divided to 2 types; early-onset and late-onset PE. Earlyonset PE typically requires early delivery (before 34 weeks' gestation) as intrauterine growth retardation, unusual uterine and umbilical artery Doppler waveforms, and negative effects on the maternal and neonatal sides are common. Late-onset PE is commonly related to mild maternal disease and a low rate of

\footnotetext{
Received: 10 November 2017, Revised: 15 December 2017, Accepted: 15 December 2017, Published: 31 December 2017

*Corresponding author: Sung Shin Shim, Ph.D.

Department of Obstetrics and Gynecology, CHA Gangnam Medical Center, CHA University, 566 Nonhyeon-ro, Gangnam-gu, Seoul 06135, Korea.

Tel: +82-2-3468-3130, Fax: +82-2-558-1112, E-mail: ogshinyss@chamc.co.kr

Conflict of interest: The authors declare that they do not have any conflicts of interest.

(c) This is an open-access article distributed under the terms of the Creative Commons Attribution Non-Commercial License (http://creativecommons.org/licenses/by-nc/4.0/) which permits unrestricted non-commercial use, distribution, and reproduction in any medium, provided the original work is properly cited.

(c) Copyright 2017 by the Korean Society of Medical Genetics and Genomics

www.e-kjgm.org
} 
fetal involvement, with delivery typically at or after 34 weeks of gestation [5-7].

Because PE can be fatal, early detection is very important, so that appropriate monitoring and clinical management can be employed. Some trials for examining PE at early and mid-gestation showed that prophylactic intervention is non-effective. However, several studies showed that prediction of PE at an early gestational age may be useful for implementing early prophylactic strategies [8].

There is no single test for predicting PE [9]. Because of the heterogenous nature of $\mathrm{PE}$, there have been efforts to combine two or more biomarkers associated with different pathophysiologies to predict the development of PE [10], such as maternal serum pregnancy-associated plasma protein-A (PAPP-A), placental growth factor (PIGF), and PP-13 [11-13]. Here, biomarkers known to predict PE are reviewed.

\section{Angiogenic Factors}

\section{Pro-angiogenic markers}

PIGF has complicated associations with pro-angiogenic factors vascular endothelial growth factor (VEGF) and PIGF, as well as their cognate receptors VEGF receptor-1 (also known as fmslike tyrosine kinase-1 [FIt-1]) and VEGF receptor-2, which is required for angiogenesis [14].

PIGF is a member of the VEGF family and is related to angiogenesis and trophoblastic invasion of the maternal spiral arteries. Median PIGF levels in the serum show a curvilinear relationship with gestational age and increase in the first and second trimesters. This level typically reaches a maximum value at approximately 30 weeks' gestation age and then decreases. In pregnancies with fetal aneuploidies with disabled placental development, PIGF levels in the maternal serum at early pregnancy (11-13 weeks' gestation) decreases, which can result in PE and small for gestational age (SGA) neonates. PIGF levels also decrease in the second and third trimesters of pregnancy when PE is advanced or in women having SGA neonates. Thus, a relationship may exist between PE and SGA neonates [15].

\section{Anti-angiogenic markers}

\section{1) Serum soluble fms-like tyrosine kinase-1}

Soluble Flt-1 (sFlt-1) is a truncated splice variant of membrane-bound Flt-1. sFlt-1 circulates in the serum without limitations and binds to and neutralizes VEGF and PIGF. Previous studies revealed a relationship between increased sFlt-1 levels and
PE [16]. As early as 5 weeks before the onset of PE, sFlt- 1 levels increase and remain elevated compared to unaffected pregnant women [17].

Since Maynard et al. [18] reported the contribution of excess sFlt-1, which is produced in the placenta, to the pathogenesis of $P E$, numerous studies have examined the usefulness of antiangiogenic markers for diagnosing, predicting, and managing PE and placenta-related disorders.

For the pathogenesis of early-onset PE, early placentation with incomplete trophoblast invasion and spiral arteries with limited remodeling are important, and may lead to lower perfusion between the uterus and placenta. In terms of the pathogenesis of $P E$, the combination of second-and third-trimester sFIt-1/PIGF ratios as predictive markers of $\mathrm{PE}$ was examined in a low-risk group. The results showed an 87.5\% detection rate with a fixed false-positive rate of 10\% for early prediction of PE [19].

\section{Pregnancy-associated Plasma Protein-A}

PAPP-A is a large highly glycosylated protein and insulin-like growth factor that binds the protein protease. It is produced by developing trophoblast cells, known as syncytiotrophoblasts [20].

The insulin-like growth factor system is known to play a critical role in placental growth and development; a relationship between higher serum PAPP-A levels and an increased incidence of PE has been observed. Although decreased PAPP-A levels in the maternal serum have been reported in PE populations, these studies only examined early second trimester pregnancy [21-23]. In a multicenter study of 8,839 women, a significant relationship between PAPP-A levels below the 5 th percentile and intrauterine growth retardation, preterm delivery, $\mathrm{PE}$, and stillbirth were observed [24].

In addition, the significance of the levels of PAPP-A in the first trimester and sFIt-1/PIGF ratio (detection rate of $87.5 \%$ with a fixed false-positive ratio of 5\%) to predict the risk of late-onset PE at the second trimester was reported [19]. Low levels of PIGF and PAPP-A in the maternal serum may reflect impaired placentation, which results in the development of PE [25].

\section{Inhibin-A and Activin-A}

Inhibin-A and activin-A are glycoproteins and members of the transforming growth factor- $\beta$ family and are released by the fetoplacental unit. It is known that inhibin-A plays an essential endocrine role in the negative feedback of gonadotropins, while 
activin-A is involved in various biological activities [26].

Inhibin-A and activin-A are also involved in the production of trophoblasts, and their high concentrations may reflect a placental compensatory mechanism for promoting trophoblastic invasion in situations where this procedure is damaged, and increases in women who will have PE [24]. Among the multiple markers for Down syndrome screening, mid-trimester inhibinA levels were reported to be the best predictor of PE $[27,28]$. An increased serum inhibin-A level was significantly related to subsequent PE; however, inhibin-A levels showed poor sensitivity for predicting PE [26,29].

\section{Placental Protein 13}

Placental protein 13 (PP-13) is a member of the galectin super-family (defined as galectin 13); this is a family of carbohydrate-binding proteins is known as $\beta$-galactoside-specific lectins in the syncytiotrophoblast $[30,31]$.

In normal pregnancies, PP13 levels in the serum gradually increase by 2-3 folds before birth [32]. Serum PP13 levels were significantly lower in patients who developed early onset PE compared to those in normal pregnancies, which can be observed as early as 5 to 7 weeks of gestation. Therefore, maternal serum levels of PP13 in the first trimester may be a reasonable marker for PE risk assessment [33,34].

\section{Cystatin C}

Cystatin $\mathrm{C}$ is an established marker of renal function; when the glomerular filtration rate decreases, cystatin $\mathrm{C}$ levels increase [35]. In PE, cystatin $\mathrm{C}$ is present in the placenta and is increased at the mRNA and protein levels, and is thus elevated in the maternal plasma [36]. Median cystatin C concentrations were found to be significantly higher in a PE group (median, $0.65 \mathrm{mg} /$ $\mathrm{L})$ than in a control group (median, $0.57 \mathrm{mg} / \mathrm{L}_{i} P=0.0001$ ) in the first trimester of pregnancy [37].

Therefore, renal function assessment plays a critical role in monitoring and predicting the severity in PE. Cystatin- $\mathrm{C}_{\text {, a novel }}$ marker for the detection of renal impairment, appears to be an early-stage PE marker.

\section{Pentraxin}

Pentraxin 3 (tumor necrosis factor-stimulated gene-14), which is composed of 381 amino acids, is a member of a family that includes $\mathrm{C}$-reactive protein and serum amyloid P com- ponent [38]. In PE, a maternal inflammatory response leads to higher levels of pentraxin 3 [39].

\section{P-Selectin}

P-Selectin is a member of the selectin group of cell surface adhesion molecules and is produced by activated platelets and endothelial cells. P-selectin supports the recruitment and activation of circulating leucocytes, as well as coagulation by generating leukocyte-derived "bloodborne" tissue factor, making it an important factor in inflammatory reactions $[40,41]$.

$\mathrm{PE}$ is known to have extensive platelet activation activities [42-44]. P-Selectin rapidly shed from the cellular membrane of activated platelets [45] and P-selectin-exposing micro-particles with procoagulant activity were detected in the peripheral blood of women with PE $[46,47]$. However, there was no significant difference in P-selectin, catalase, and superoxide dismutase between PE (case group) and pregnant women with normal blood pressure (control group) in a recent study [48]. To date, various aspects of P-selectin activity were reported to be affected by PE. Thus, it is important to determine the complex interactions of $\mathrm{P}$ selectin in context-specific situations of PE.

\section{Genetic Markers for Pre-eclampsia}

Genes in various biological pathways related to the immune system, control of vascular resistance, blood coagulation, cell signaling pathways, and metabolic processes, are thought to cause PE and its complications [49].

A meta-analysis in the Human Genome Epidemiology Review revealed a relatively high risk association of severe $P E$ with the coagulation factor $\mathrm{V}$ gene (proaccelerin, labile factor) (F5) polymorphism rs6025 (odds ratio [OR] $=1.90,95 \%$ confidence interval [Cl]: 1.42-2.54; 23 studies, $I^{2}=29 \%$ ), coagulation factor II (thrombin) gene (F2) mutation G20210A (rs1799963) (OR=2.01, 95\% Cl: 1.14-3.55; 9 studies, $I^{2}=0 \%$ ), leptin receptor gene polymorphism rs 1137100 (OR=1.75, 95\% Cl: 1.15-2.65; 2 studies, $\left.\mathrm{I}^{2}=0 \%\right)$, and thrombophilic gene group ( $\mathrm{OR}=1.87,95 \% \mathrm{Cl}: 1.43$ $\left.2.45 ; i^{2}=27 \%\right)[49]$.

In another study in 2012, seven genetic variants related to PE were found angiotensin-converting enzyme, cytotoxic T-lymphocyte-associated protein 4, factor 2, factor V (two variants), lipoprotein lipase, and serine peptidase inhibitor 1 genes. This meta-analysis suggested a relationship between PE and systems such as the renin-angiotensin system, coagulation and fibrinolysis system, and system of lipid metabolism and inflammation 
[50]. However, genetic factors of PE remain unclear, and further studies are needed to determine the influence of genetic factors on PE.

\section{Cell-free DNA}

There is now a wealth of data showing that cell-free DNA (cffDNA) has immunostimulatory properties via complex molecular mechanisms [51]. Human fetal DNA modulates immunity through nuclear factor (NF)- $\kappa$ B activation in vitro has been demonstrated by Scharfe-Nugent et al. [52], who found that $\mathrm{NF}-\kappa \mathrm{B}$ activation resulted in the production of proinflammatory interleukin-6 in human B-cells and peripheral blood mononuclear cells. This occurs in both pregnant and non-pregnant groups. Fetal DNA is produced in the placenta. The relationship between fetal DNA and PE was recently investigated and higher fetal DNA was observed in the group with a greater risk of developing PE. Additionally, the highest level of fetal DNA was found in women with HELLP syndrome $[53,54]$.

Lo et al. [55] reported the possibility of detecting cffDNA in the maternal plasma based on PE index. They observed that plasma cffDNA in the third trimester was increased by approximately 5 -fold in 20 PE women compared to in 20 pregnant women (age-matched) controls. Many studies of using cffDNA as a predictor of PE are currently underway, and its combination with other markers has been reported as a potential predictor of PE (e.g., P-selectin, PAPP-A, PP-13, sFlt-1, and PIGF) [56]. Among 13 studies of the quantity of cffDNA suitable for predicting PE, 11 studies showed higher cffDNA in women who developed PE and 4 studies showed that cffDNA was increased in the maternal plasma before the onset of PE [57].

MicroRNAs (miRNAs) are noncoding RNA transcripts account for approximately $2 \%$ of human genes. MiRNAs are critical posttranscriptional regulators of gene expression in both healthy people and people with diseases [58]. In healthy term placenta, miRNA levels were evaluated [59-61]; in cases of placental insufficiency, miRNA levels were altered, indicating that miRNAs are useful predictors of PE [59-64]. In a study by Murphy et al. [65] in 2015, circulating miRNA profiles were identified at the time of delivery and at 1 year postpartum in PE and control groups by quantitative reverse transcription-PCR, and seven maternal plasma miRNAs (miR-98, miR-222, miR-210, miR-155, miR-296, miR-181a, and miR-29b) were increased in women with severe PE. Recent studies of placenta-specific miRNAs in the maternal circulation also indicated their potential as predictive markers of placental insufficiency [66-69].

\section{Conclusion}

PE is well known as an important disease related to maternal morbidity and mortality. Many studies have attempted to identify the causes of PE. While many factors involved in the pathophysiology of PE have been suggested, the precise causes of PE remain unknown.

Many different factors are related to the pathophysiology of PE [70]. Some of these factors can help clinicians predict PE and enable management to being in the first trimester. However, further studies of the causes of PE are needed, which help to predict PE earlier and more accurately improving treatment.

Thus, additional studies are needed to elucidate the molecular biomarkers and genetics, such as DNA and miRNA for predicting PE. Additionally, large-scale, multicenter, multi-ethnic, prospective trials considering different possibilities to develop PE prediction are required to identify better combinations of markers for screening PE.

\section{References}

1. Duley L. The global impact of pre-eclampsia and eclampsia. Semin Perinatol 2009;33:130-7.

2. Spencer-Jones J. Make every mother and child count. S Afr Med J 2005;95:382, 384

3. Lyons G. Saving mothers'lives: confidential enquiry into maternal and child health 2003-5. Int J Obstet Anesth 2008;17:103-5.

4. Warrington JP, George EM, Palei AC, Spradley FT, Granger JP. Recent advances in the understanding of the pathophysiology of preeclampsia. Hypertension 2013;62:666-73.

5. Irgens HU, Reisaeter L, Irgens LM, Lie RT. Long term mortality of mothers and fathers after pre-eclampsia: population based cohort study. BMJ 2001;323:1213-7.

6. Yu CK, Khouri O, Onwudiwe N, Spiliopoulos Y, Nicolaides KH; Fetal Medicine Foundation Second-Trimester Screening Group. Prediction of pre-eclampsia by uterine artery Doppler imaging: relationship to gestational age at delivery and small-for-gestational age. Ultrasound Obstet Gynecol 2008;31:310-3.

7. Witlin AG, Saade GR, Mattar F, Sibai BM. Predictors of neonatal outcome in women with severe pre-eclampsia or eclampsia between 24 and 33 weeks' gestation. Am J Obstet Gynecol 2000;182:607-11.

8. Thilaganathan B, Wormald B, Zanardini C, Sheldon J, Ralph E, Papageorghiou AT. Early-pregnancy multiple serum markers and secondtrimester uterine artery Doppler in predicting preeclampsia. Obstet Gynecol 2010;115:1233-8.

9. Zhong $Y$, Tuuli $M$, Odibo AO. First-trimester assessment of placenta 
function and the prediction of preeclampsia and intrauterine growth restriction. Prenat Diagn 2010;30:293-308.

10. Scazzocchio E, Figueras F. Contemporary prediction of preeclampsia. Curr Opin Obstet Gynecol 2011;23:65-71.

11. Cuckle HS. Screening for pre-eclampsia--lessons from aneuploidy screening. Placenta 2011;32 Suppl:S42-8.

12. Nicolaides $K H_{1}$, Bindra $R$, Turan $O M$, Chefetz I, Sammar $M$, Meiri $H_{1}$ et al. A novel approach to first-trimester screening for early pre-eclampsia combining serum PP-13 and Doppler ultrasound. Ultrasound Obstet Gynecol 2006;27:13-7.

13. Anderson UD, Gram M, Jälmby M, Kerström B, Hansson SR. [167-POS] : The human endogenous protection system against cell-free hemoglobin is overwhelmed during preeclampsia - New biomarkers and potential targets for therapy. Pregnancy Hypertens 2015;5:86.

14. Tjwa M, Luttun A, Autiero $M$, Carmeliet P. VEGF and PIGF: two pleiotropic growth factors with distinct roles in development and homeostasis. Cell Tissue Res 2003;314:5-14.

15. Tsiakkas A, Duvdevani N, Wright A, Wright D, Nicolaides KH. Serum placental growth factor in the three trimesters of pregnancy: effects of maternal characteristics and medical history. Ultrasound Obstet Gynecol 2015;45:591-8.

16. Kar M. Role of biomarkers in early detection of preeclampsia. J Clin Diagn Res 2014;8:BE01-4.

17. Levine RJ, Maynard SE, Qian C, Lim KH, England L, Yu KF, et al. Circulating angiogenic factors and the risk of preeclampsia. N Engl J Med 2004;350:672-83.

18. Maynard SE, Min JY, Merchan J, Lim KH, Li J, Mondal S, et al. Excess placental soluble fms-like tyrosine kinase 1 (sFlt1) may contribute to endothelial dysfunction, hypertension, and proteinuria in preeclampsia. J Clin Invest 2003;111:649-58.

19. Park HJ, Kim SH, Jung YW, Shim SS, Kim JY, Cho YK, et al. Screening models using multiple markers for early detection of late-onset preeclampsia in low-risk pregnancy. BMC Pregnancy Childbirth 2014;14:35.

20. Lawrence JB, Oxvig C, Overgaard MT, Sottrup-Jensen L, Gleich GJ, Hays LG, et al. The insulin-like growth factor (IGF)-dependent IGF binding protein-4 protease secreted by human fibroblasts is pregnancy-associated plasma protein-A. Proc Natl Acad Sci U S A 1999:96:3149-53

21. Deveci K, Sogut E, Evliyaoglu O, Duras N. Pregnancy-associated plasma protein-A and C-reactive protein levels in pre-eclamptic and normotensive pregnant women at third trimester. J Obstet Gynaecol Res 2009;35:94-8.

22. Bersinger NA, Ødegård RA. Second- and third-trimester serum levels of placental proteins in preeclampsia and small-for-gestational age pregnancies. Acta Obstet Gynecol Scand 2004;83:37-45.
23. Bersinger NA, Smárason AK, Muttukrishna $S$, Groome NP, Redman CW. Women with preeclampsia have increased serum levels of pregnancy-associated plasma protein A (PAPP-A), inhibin A, activin A and soluble E-selectin. Hypertens Pregnancy 2003;22:45-55.

24. Smith GC, Stenhouse EJ, Crossley JA, Aitken DA, Cameron AD, Connor JM. Early pregnancy levels of pregnancy-associated plasma protein a and the risk of intrauterine growth restriction, premature birth, preeclampsia, and stillbirth. J Clin Endocrinol Metab 2002;87:1762-7.

25. Poon LC, Akolekar R, Lachmann R, Beta J, Nicolaides KH. Hypertensive disorders in pregnancy: screening by biophysical and biochemical markers at 11-13 weeks. Ultrasound Obstet Gynecol 2010;35:662-70.

26. Muttukrishna S, North RA, Morris J, Schellenberg JC, Taylor RS, Asselin J, et al. Serum inhibin $A$ and activin $A$ are elevated prior to the onset of pre-eclampsia. Hum Reprod 2000;15:1640-5.

27. Kang JH, Farina A, Park JH, Kim SH, Kim JY, Rizzo N, et al. Down syndrome biochemical markers and screening for preeclampsia at first and second trimester: correlation with the week of onset and the severity. Prenat Diagn 2008;28:704-9.

28. Ree PH, Hahn WB, Chang SW, Jung SH, Kang JH, Cha DH, et al. Early detection of preeclampsia using inhibin a and other second-trimester serum markers. Fetal Diagn Ther 2011;29:280-6.

29. Sibai BM, Koch MA, Freire S, Pinto e Silva JL, Rudge MV, MartinsCosta $\mathrm{S}$, et al. Serum inhibin A and angiogenic factor levels in pregnancies with previous preeclampsia and/or chronic hypertension: are they useful markers for prediction of subsequent preeclampsia? Am J Obstet Gynecol 2008;199:268.e1-9.

30. Than NG, Romero $R$, Goodman $M$, Weckle $A$, Xing J, Dong $Z$, et al A primate subfamily of galectins expressed at the maternal-feta interface that promote immune cell death. Proc Natl Acad Sci U S A 2009;106:9731-6.

31. Than NG, Romero R, Kim CJ, McGowen MR, Papp Z, Wildman DE. Galectins: guardians of eutherian pregnancy at the maternal-fetal interface. Trends Endocrinol Metab 2012;23:23-31.

32. Huppertz B. Placental origins of preeclampsia: challenging the current hypothesis. Hypertension 2008;51:970-5.

33. Huppertz B, Sammar M, Chefetz I, Neumaier-Wagner P, Bartz C, Meiri H. Longitudinal determination of serum placental protein 13 during development of preeclampsia. Fetal Diagn Ther 2008;24:230-6.

34. Gonen $R$, Shahar $R$, Grimpel $Y I_{1}$ Chefetz I, Sammar M, Meiri $H_{\text {, et al. }}$ Placental protein 13 as an early marker for pre-eclampsia: a prospective longitudinal study. BJOG 2008;115:1465-72.

35. Grubb AO. Cystatin C--properties and use as diagnostic marker. Adv Clin Chem 2000;35:63-99.

36. Kristensen K, Larsson I, Hansson SR. Increased cystatin C expression in the pre-eclamptic placenta. Mol Hum Reprod 2007;13:189-95.

37. Thilaganathan B, Ralph E, Papageorghiou AT, Melchiorre K, Sheldon 
J. Raised maternal serum cystatin C: an early pregnancy marker for preeclampsia. Reprod Sci 2009;16:788-93.

38. Souza DG, Soares AC, Pinho V, Torloni $H$, Reis LF, Teixeira MM, et al. Increased mortality and inflammation in tumor necrosis factorstimulated gene-14 transgenic mice after ischemia and reperfusion injury. Am J Pathol 2002;160:1755-65.

39. Cetin I, Cozzi V, Pasqualini F, Nebuloni M, Garlanda C, Vago L, et al. Elevated maternal levels of the long pentraxin 3 (PTX3) in preeclampsia and intrauterine growth restriction. Am J Obstet Gynecol 2006;194:1347-53.

40. André P. P-selectin in haemostasis. Br J Haematol 2004;126:298-306.

41. Polgar J, Matuskova J, Wagner DD. The P-selectin, tissue factor, coagulation triad. J Thromb Haemost 2005;3:1590-6.

42. Holthe MR, Staff AC, Berge LN, Lyberg T. Different levels of platelet activation in preeclamptic, normotensive pregnant, and nonpregnant women. Am J Obstet Gynecol 2004;190:1128-34.

43. Konijnenberg A, Stokkers EW, van der Post JA, Schaap MC, Boer $K$, Bleker $\mathrm{OP}$, et al. Extensive platelet activation in preeclampsia compared with normal pregnancy: enhanced expression of cell adhesion molecules. Am J Obstet Gynecol 1997;176:461-9.

44. Yoneyama Y, Suzuki S, Sawa R, Kiyokawa Y, Power GG, Araki T. Plasma adenosine levels and P-selectin expression on platelets in preeclampsia. Obstet Gynecol 2001;97:366-70.

45. Dunlop LC, Skinner MP, Bendall $\amalg$, Favaloro EJ, Castaldi PA, Gorman $J$ J, et al. Characterization of GMP-140 (P-selectin) as a circulating plasma protein. J Exp Med 1992;175:1147-50.

46. Bretelle F, Sabatier F, Desprez D, Camoin L, Grunebaum L, Combes V, et al. Circulating microparticles: a marker of procoagulant state in normal pregnancy and pregnancy complicated by preeclampsia or intrauterine growth restriction. Thromb Haemost 2003;89:486-92.

47. Lok CA, Nieuwland R, Sturk A, Hau CM, Boer K, Vanbavel E, et al. Microparticle-associated $\mathrm{P}$-selectin reflects platelet activation in preeclampsia. Platelets 2007;18:68-72.

48. Nasrollahi S, Hoseini Panah SM, Tavilani H, Tavasoli S, Naderan M, Shoar S. Antioxidant status and serum levels of selectins in preeclampsia. J Obstet Gynaecol 2015;35:16-8.

49. Fong FM, Sahemey MK, Hamedi G, Eyitayo R, Yates D, Kuan V, et al. Maternal genotype and severe preeclampsia: a HuGE review. Am J Epidemiol 2014;180:335-45.

50. Buurma AJ, Turner RJ, Driessen JH, Mooyaart AL, Schoones JW, Bruijn $J A$, et al. Genetic variants in pre-eclampsia: a meta-analysis. Hum Reprod Update 2013;19:289-303.

51. Isaacs A, Cox RA, Rotem Z. Foreign nucleic acids as the stimulus to make interferon. Lancet 1963;2:113-6.

52. Scharfe-Nugent A, Corr SC, Carpenter SB, Keogh L, Doyle B, Martin C, et al. TLR9 provokes inflammation in response to fetal DNA: mecha- nism for fetal loss in preterm birth and preeclampsia. J Immunol 2012;188:5706-12.

53. Miranda ML, Macher HC, Muñoz-Hernández R, Vallejo-Vaz A, Moreno-Luna $R$, Villar J, et al. Role of circulating cell-free DNA levels in patients with severe preeclampsia and HELLP syndrome. Am J Hypertens 2013;26:1377-80.

54. Tjoa ML, Cindrova-Davies T, Spasic-Boskovic O, Bianchi DW, Burton GJ. Trophoblastic oxidative stress and the release of cell-free fetoplacental DNA. Am J Pathol 2006;169:400-4.

55. Lo YM, Leung TN, Tein MS, Sargent IL, Zhang J, Lau TK, et al. Quantitative abnormalities of fetal DNA in maternal serum in preeclampsia. Clin Chem 1999;45:184-8.

56. Grill S, Rusterholz C, Zanetti-Dällenbach R, Tercanli S, Holzgreve W, Hahn S, et al. Potential markers of preeclampsia--a review. Reprod Biol Endocrinol 2009;7:70.

57. Martin A, Krishna I, Badell M, Samuel A. Can the quantity of cell-free fetal DNA predict preeclampsia: a systematic review. Prenat Diagn 2014;34:685-91.

58. Alvarez-Garcia I, Miska EA. MicroRNA functions in animal development and human disease. Development 2005;132:4653-62.

59. Enquobahrie DA, Abetew DF, Sorensen TK, Willoughby D, Chidambaram K, Williams MA. Placental microRNA expression in pregnancies complicated by preeclampsia. Am J Obstet Gynecol 2011;204:178 e12-21.

60. Mayor-Lynn K, Toloubeydokhti T, Cruz AC, Chegini N. Expression profile of microRNAs and mRNAs in human placentas from pregnancies complicated by preeclampsia and preterm labor. Reprod Sci 2011;18:46-56.

61. Wang $W$, Feng L, Zhang $H$, Hachy $S$, Satohisa $S$, Laurent LC, et al. Preeclampsia up-regulates angiogenesis-associated microRNA (i.e., miR-17, -20a, and -20b) that target ephrin-B2 and EPHB4 in human placenta. J Clin Endocrinol Metab 2012;97:E1051-9.

62. Choi SY, Yun J, Lee OJ, Han HS, Yeo MK, Lee MA, et al. MicroRNA expression profiles in placenta with severe preeclampsia using a PNAbased microarray. Placenta 2013;34:799-804.

63. Pineles BL, Romero R, Montenegro D, Tarca AL, Han YM, Kim YM, et al. Distinct subsets of microRNAs are expressed differentially in the human placentas of patients with preeclampsia. Am J Obstet Gynecol 2007;196:261.e1-6.

64. Zhu XM, Han T, Sargent IL, Yin GW, Yao YO. Differential expression profile of microRNAs in human placentas from preeclamptic pregnancies vs normal pregnancies. Am J Obstet Gynecol 2009;200:661. e1-7.

65. Murphy MS, Casselman RC, Tayade C, Smith GN. Differential expression of plasma microRNA in preeclamptic patients at delivery and 1 year postpartum. Am J Obstet Gynecol 2015;213:367.e1-9. 
66. Hromadnikova I. Extracellular nucleic acids in maternal circulation as potential biomarkers for placental insufficiency. DNA Cell Biol 2012;31:1221-32.

67. Hromadnikova I, Kotlabova K, Doucha J, Dlouha K, Krofta L. Absolute and relative quantification of placenta-specific micrornas in maternal circulation with placental insufficiency-related complications. J Mol Diagn 2012;14:160-7.

68. Pan M, Ge O, Li H, Yang Q, Lu J, Zhang D, et al. Sequencing the miR-
NAs in maternal plasma from women before and after parturition. J Nanosci Nanotechnol 2012;12:4035-43.

69. Chim SS, Shing TK, Hung EC, Leung TY, Lau TK, Chiu RW, et al. Detection and characterization of placental microRNAs in maternal plasma. Clin Chem 2008;54:482-90.

70. Roberts JM, Bell MJ. If we know so much about preeclampsia, why haven't we cured the disease? J Reprod Immunol 2013;99:1-9. 